IP Periodica Polytechnica

Social and Management

Sciences

23(1), pp. 15-24, 2015

DOI: $10.3311 /$ PPso. 7966

Creative Commons Attribution (i)

RESEARCH ARTICLE

\section{The Role of Investment Promotion Agencies in Attracting Foreign Direct Investments in the Southeast European Countries}

\author{
Ines Kersan-ŠSkabić ${ }^{*}$
}

Received 29 August 2014; accepted 11 February 2015

\begin{abstract}
This paper aims to assess the role of national and regional agencies in attracting foreign direct investment (FDI) in the Southeast European (SEE) countries and to connect the findings from IPA's staff with the determinants of FDI inflows. The research is conducted using survey data and panel data analysis. The results indicate small, inadequate, and unexploited potential of investment promotion agencies (IPAs). They have participated in a small number of FDI projects and most of the FDIs came into the region without their participation. They do not have a qualitative approach to FDI. Most of the regional agencies (except in Croatia and Kosovo) do not even envisage cooperation with foreign investors. The panel data research has shown that GDP per capita, wages, inflation (as economic variables), but also enterprise restructuring, tax rates, trade and forex system (institutional variables) have influence on FDI inward stock.
\end{abstract}

\section{Keywords}

FDI, investment promotion agencies, SEE region, cluster analysis, panel data analysis

\footnotetext{
${ }^{1}$ Juraj Dobrila University of Pula,

Faculty of Economics and Tourism "Dr. Mijo Mirković"

52100 Pula, P.Preradovica 1 Croatia

*Corresponding author, e-mail: ikersan@unipu.hr
}

\section{Introduction}

Foreign Direct Investments (FDIs) inflows can play an important role in the development and competitiveness of countries. The impact of FDI on growth is expected to be manifold and its influence depends on the sector orientation and kind of FDI (Damijan et al., 2013). Greenfield FDIs are considered to be more desirable for the host country because they point to new production, which leads to additional and new employment, brings new technologies, know-how, higher levels of efficiency, and productivity. This can have a positive impact on domestic firms, which can learn from them. FDIs are not always just positive as it depends on the development stage and characteristics of host countries, that is, because of the lack of competitiveness and export performance of domestic firms, entry of foreign firms can destroy domestic economy (Mencinger, 2003).

Countries have conventionally been working to encourage the inflow of FDI because of the expected benefits of FDIs. They usually do this through a list of incentives given to foreign investors as defined in the laws for promoting investments (fiscal and financial incentives). Many countries have established specialized agencies as the push factor and information corner for investors. In the literature there are many determinants of FDI inflow such as: market size, market growth, barriers to trade, wages, production, transportation and other costs, political stability, psychic distance, and host government's trade and taxation regulations that affected location decisions (Dunning, 1992; Dunning, 1993; Kinoshita and Campos, 2002; Markusen, 1998; Markusen and Venables, 1998; Hunya, 2000; Brainard, 1997; Blonigen, 2005). All these factors can be measured and are included in different econometric models.

Existing researches have given less attention to investment promotion agencies (IPA). The IPAs are important because they are one-stop-shop points for foreign investors and their support (adequate information, knowledge, availability, professionalism, help) can be invaluable for attracting FDI inflows. These agencies do some kind of marketing of a country through the following technics: image building, investment generating, and investor services (Wells, 1999). IPAs are in close contact with 
foreign investors (providing services) and they obtain detailed knowledge about the problems that investors face. It enables the agencies to make or to propose necessary reforms (responsible ministries usually do not have such kind of concrete information). Although there is no clear evidence and proof of effectiveness of IPAs, governments continue to increase expenditure on investment promotion because many national and subnational governments view foreign investments as a precondition for economic development.

Wells and Wint (1990) conducted the earliest study on the effect of IPAs on FDI flows and they have found that investment promotion is significantly correlated with the level of FDI per capita in a sample of 50 countries. Cass (2006) used an assessment-based approach to determine the extent and intensity of IPA activities, concentrating on the three "classical" IPA tasks: Investor Services, Image Building, and Investor Generation. On the basis of analysis made in 27 countries, he points that the establishment and development of IPAs have been influenced by active participation in international competition for export-oriented investment linked to progress in transition. He also warns that incentives are important in the early stage of liberalization (transition), but Wells (1999) shows their importance at three phases: pre-investment decision, implementation of investment, and post-investment stage.

According to data from The World Association of Investment Promotion Agencies (WAIPA), the Association counted 165 member agencies from 122 countries. IPAs refer to different agencies, government body, or other entity on national or regional level whose prime function is to promote any country as a destination for or as source of investments (WAIPA, 2012).

The goal of this paper is to focus on the role of IPAs in the Southeast European (SEE) countries in attracting FDI inflows. There are different ways of assessing the role and scope of IPAs (their role in investment process, their budget, staff, and responsibilities). We wanted to determine the contribution of IPAs to the FDI inflows as they most often provided information to foreign investors, their attitudes on: the reasons for investment in a particular area (country/region), benefits and disadvantages of FDI, and obstacles and unfavourable effects of inward FDI. We will confront their attitudes with the result of econometric analysis pointing the role of selected institutional variables. Additionally, we want to determine the qualitative aspect of IPAs (according to the country's strategies) that is, their focus to attract investment in particular sectors (through reliefs and specialized staff). The research is done using survey data and panel data analysis.

The contribution of this paper is the focus on the specific geographical region, which has not been studied separately. There are few studies where some of the SEE countries were included. An UNCTAD study (UNCTAD, 2001) of IPAs worldwide included aggregated data on 15 agencies in Central and Eastern Europe (covering activities, resources, priorities, issues, and organization). Morisset and Andrews-Johnson (2004) included nine transition countries in their survey of the effectiveness of IPAs but reported only aggregate findings. Kunčič and Svetličič (2011) have included in the analysis a few SEE countries. This paper aims to include the following countries: Albania, Bosnia and Herzegovina, Croatia, Kosovo, Macedonia, Montenegro and Serbia. As most of these former socialist countries were affected by war in the first half of 1990s, they began the process of liberalization later than countries in Central and East Europe (CEE). These countries also faced a weak institutional development (with the trend of improvement) where IPAs are a part of institutional infrastructure. The first wave of FDI inflows was oriented toward buying the ownership share in the existing firms through so-called brownfield FDI (privatization process). As usual, there was also the competition arising among countries in attracting FDIs through different incentives (tax holidays and reliefs) proposed by their governments. Initially, countries wanted to receive many FDIs with no or limited care about which sectors those investments were targeted. Only two countries from the region (Croatia and Montenegro) have attracted significant levels of FDI per capita (EUR 5,787 and 6,500, respectively), whereas the rest of the SEE region suffers from low attractiveness. With time, all SEE countries have started to build their country's images (relatively late in comparison with CEE countries) and have established special agencies for promoting countries and for providing services to foreigners who want to invest. The role of IPAs is to overcome market imperfections and information asymmetries and ensure information availability and dissemination to foreign investors.

The paper is organized as follows: the following section presents the literature review, the third section describes the data, the methodology of research and presents the results and the final section gives the concluding remarks.

\section{Literature review}

Establishing an IPA has become the most popular institutional approach in strategic FDI promotion across nations and regions worldwide (OECD, 2006). The general purpose of IPAs is to increase the international visibility of the country (or region) through marketing campaigns and to facilitate the investment process by offering tailored services and incentives to foreign corporations, both before and after the initial investment (Guimon and Filippov, 2012). The overview of IPAs tasks is given in Table 1 .

Usually, the activities of IPAs are focused on boosting inflows of FDI via a quantitative approach because these investments should promote increase of production and generate new employment. As the quantity of FDI inflows grow in a country (particularly in developed countries), they gradually attract more qualitative FDIs, which contribute significantly to the national and regional competitiveness. 
Basinger and Hallerberg (2004) explain this new trend as $a$ race to the top (competition in asset creation) as opposed to the classical race to the bottom (competition based on lower costs and taxes). Kemeny (2010) warns that such a positive evolution is not automatic and it is necessary to raise local capabilities and absorptive capacity. Regarding the differences between quantitative and qualitative FDIs there are also differences in the measurement of their effectiveness.

Table 1 Functions of IPAs

\begin{tabular}{|c|c|c|c|}
\hline & Function & Description & Example of means \\
\hline \multirow{3}{*}{ 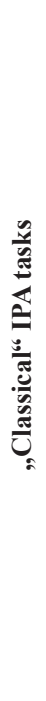 } & $\begin{array}{c}\text { Investor } \\
\text { facilitation and } \\
\text { investor services }\end{array}$ & $\begin{array}{l}\text { Assisting an investor } \\
\text { to analyze his } \\
\text { decision, establish a } \\
\text { business and ensure it } \\
\text { continues to operate }\end{array}$ & $\begin{array}{c}\text { Provision of } \\
\text { information, } \\
\text { assistance in getting } \\
\text { approvals, assistance } \\
\text { with sites, utilities, } \\
\text { etc. }\end{array}$ \\
\hline & Image building & $\begin{array}{l}\text { Creating the } \\
\text { perception of a } \\
\text { country as an } \\
\text { attractive site }\end{array}$ & $\begin{array}{l}\text { Advertising and } \\
\text { public relations }\end{array}$ \\
\hline & $\begin{array}{l}\text { Investment } \\
\text { generation }\end{array}$ & $\begin{array}{l}\text { Targeting specific } \\
\text { sectors and } \\
\text { companies in order } \\
\text { to create investment } \\
\text { leads }\end{array}$ & $\begin{array}{l}\text { Identification of } \\
\text { targets, direct } \\
\text { contact, forums, } \\
\text { seminars, etc. }\end{array}$ \\
\hline 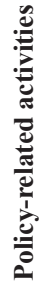 & Policy advocacy & $\begin{array}{l}\text { Supporting initiatives } \\
\text { to improve the } \\
\text { investment climate } \\
\text { and identifying } \\
\text { private sector views. }\end{array}$ & $\begin{array}{c}\text { Surveys, } \\
\text { participation in } \\
\text { task forces, policy } \\
\text { proposals, lobbying. }\end{array}$ \\
\hline
\end{tabular}

Source: Cass (2006), Morisset and Andrews-Johnson (2004).

Evaluation of IPAs is very complex and in an optimal case, it will include external (funder, national government, international organization) and internal dimensions (staff characteristics, financing, number of projects,...) (UNCTAD, 2008).

Raines and Wishlade (1999) warn that there is competition not only among countries but also among regions within countries. Hughes and Helinska-Hughes (2002) have presented case studies of four countries and find that the core services of IPAs in all agencies are the same and the difference is that IPAs in developed (West European) countries have adopted a more proactive stance with direct contacts to individual firms. It is not clear if such behaviour reflects a more sophisticated and effective approach, or the availability of more resources, or perhaps just a measure of despair. There is also evidence of an increase in the number of institutions at the national and regional levels in the observed four countries that act in attracting FDIs but they are loosely coordinated.
Morisset (2003) used data from a survey of 58 countries and shows that greater investment promotion is associated with higher cross-country FDI flows. The effectiveness of IPAs depends on: the country's environment in which it operates, scope of activities that an agency undertakes influences its performance, and certain internal characteristics of the agencies.

Charlton and Davies (2007) researched if the existence of IPAs increased the inflows of FDI, that is, if the IPAs have justified their establishment and financing from the government budget. They found a positive effect of investment promotion in terms of robust FDI inflows across various empirical specifications. IPAs focusing on small number of sectors have proven to be a very good policy because such a targeting increases FDI inflows in that industry by $41 \%$.

Guimon (2009) focused his research on the necessary activities of IPAs to attract more qualitative FDIs (in research and development sector) in Spain and Ireland and conclude that it is necessary to encourage close cooperation between IPAs and innovation policy in a country because they are two policy areas that have traditionally operated separately. It is also recommended that IPAs targeting R\&D-intensive FDI to reconfigure the scope of services they provide by placing more emphasis on aftercare, as R\&Dintensive FDI tends to be evolutionary rather than purely greenfield. Guimon and Filippov (2012) point that shifting emphasis from quantity to quality in FDI promotion entails a new policy mix and a new approach to performance evaluation. They offer a broad framework to better guide FDI policy reform considering the interaction between the IPAs targeting quality from an intellectual capital management perspective.

Deichmann (2010) and Kunčić and Svetličić (2011) have analysed the attitudes of the employees in IPAs or other promoting agencies because they also influence, shape, and implement the policies for FDI. Although Deichman's research was focused on the Czech Republic, Kunčić and Svetličič (2011) have applied a survey approach and cluster analysis to determine the effectiveness of FDI IPAs in Europe and the Western Balkans. The results are profiled in three sets of beliefs or attitudes toward FDI: "pessimistic," "Keynesian," and "neoclassical." Keynesians largely favour fiscal measures for attracting FDI, whereas neoclassical dislike fiscal measures and government interventions and prefer good economic fundamentals, infrastructure, and qualified personnel. Most of the Eastern European Union as well as South-eastern European respondents can be classified as Keynesians.

Šymelite (2012) found that investment promotion has a strong effect on FDI on condition that investment promotion is introduced in full in the Baltic states.

As Lim (2008) points out, it is necessary to decide if we should look at the IPA as a determinant of FDI inflows or mediator for FDI attractiveness between the host country's environment and FDI inflows. An IPA's (promotion) activity has been considered as a part of business facilitation (UNCTAD, 1998), 
but it is not clearly argued as to how an IPA's activity affects FDI inflows. Our approach is in line with Lim (2008) because of a few reasons: the IPAs in the SEE region have existed for a relatively short period; they do not create business environment (they can help to explain it and make it closer to investors); they are very small in terms of number of employees, and, as most of them do not have a specific budget for FDI activities, they cannot be considered as a determinant for FDI inflows (there are other market and resource-seeking determinants of FDI). The IPAs are a part of institutional infrastructure.

\section{Empirical research}

\subsection{Data and methodology}

The analysis of IPAs role in attracting of FDI was conducted on the seven SEE countries ${ }^{1}$. The research consists of two parts: survey analysis (1) and panel data analysis (2).

\section{(1) Survey analysis}

The sample of agencies includes national agencies for FDI promoting and regional development agencies. All observed countries have national agencies for FDI promoting ${ }^{2}$. On the regional level the number, organization, and responsibilities of agencies differs not only among countries but also among regions in the same country. Among the observed countries, only Croatia is in the EU membership that can give positive impact on its institutions and activities of agencies. There are 21 accredited regional agencies (or similar bodies) in Croatia that primarily focuses on promoting regional development, entrepreneurship, and absorption of the EU funds. Serbia has 10 regional accredited agencies that are focused to provide support to local businesses and local municipalities in the creation of local development/infrastructure plans. There are four regional development agencies in Kosovo (North, East, South, and West), and for Albania we cannot determine the exact number of regional agencies. In Macedonia, there are three institutions in charge of promoting local development, whereas in Bosnia and Herzegovina there are five regional agencies. Although Montenegro has two regional bodies, they are not responsible for communication with foreign investors; the entire promoting activities are executed at the national level (national agency for investment promoting). It is also important to mention the establishment of SEENORDA (South East Europe Network of

1 Albania, Bosnia and Herzegovina, Croatia, Former Yugoslav Republic of Macedonia, Kosovo, Montenegro, and Serbia.

2 For example: Agency for invesments and competitiveness (Croatia), Foreign Investment Promotion Agency of Bosnia and Herzegovina; Serbia Investment and Export Promotion Agency, Agency for Foreign Investments, and Export Promotion of the Republic of Macedonia, etc. The situation in Croatia is strange because there was the (national) Agency for promoting export and investments until the end of 2011 and later a new agency (Agency for investments and competitiveness) was established with the new staff and organizational structure, which is not transparent and not good policy for the cooperation with potential investors from abroad.
Regional Development Agencies) as a network of 19 regional development agencies in Macedonia, Kosovo, Croatia, Bosnia and Herzegovina, Bulgaria, Turkey, Albania, and Montenegro.

We are focused on the assessing the scope of activities, services provided to investors, and qualitative aspect of IPAs. Initial assumption is that IPAs deal as a mediator between the host country environment and foreign investors (and they compensate for market failures) (Lim, 2008).

The research was conducted by survey, which was sent to 77 institutions (national agencies, regional agencies, chambers of commerce, or similar institutions that may deal with foreign investors). The questionnaire consisted of 33 questions, both qualitative and quantitative. In the first part of survey, the respondents had to answer on general questions about the name, year of establishment, number of employees, educational structure of employees, and so on. The second part of the survey pertains to their role (services, activities) in attracting FDI. The survey consists of 16 multiple choice questions, six "yes/no" questions with possibilities for explanations, two questions are graded according to Likert scale, four questions are rankings, and the rest are "open" type questions ${ }^{3}$. The questionnaire was sent to the target group on February 10, 2014, and the time for responding was until the end of February (with one reminder).

\section{(2) Panel data analysis}

In the second part of research we have proceed with the econometric analysis of determinants of FDI putting in the model specific variables that IPA's staff has been recognized as the main reasons (and information provided to foreign investors) and obstacles for attraction more FDI. There are many researches of determinants of FDI and the idea here is not just making another research on a particular group of countries. The aim is to indicate if the IPA staff, which communicate with foreign investors, have right opinion and impression about the main shortages in their economies which should be improved if the countries want to be more attractive and reliable host economies for foreign investments.

The detected obstacles are in area of institutional development, which has been researched by La Porta et al. (1999), Egger \& Winner (2005), Kaufmann, Kraay \& Mastruzzi (2004), Bénassy-Quéré et al. (2007). The dependent variable in our models will be FDI inward stock and independent variables: GDP per capita, inflation, wages, corporate tax rates, and institutional variables. The data for GDP per capita, FDI inward stock, inflation and wages are from WIIW (2013) while the main sources for institutional variables are: the EBRD transition indicators, Economic Freedom data (The Heritage Foundation), and Transparency International.

The European Bank for Reconstruction and Development publishes the Transition Report, in which it processes many

3 Some of the questions follow the questionnaire of Kunčić and Svetličić (2011). 
indicators to assess improvements in restructuring of economies. The scores are from 1 to $4+$, and are based on an assessment of the size of challenges in terms of two components: market structure and market-supporting institutions and policies. They measure the transition gap (deviation from efficient market structure). Score 1 to 2 means that there is a large transition gap, and score 4 or $4+$ means that this gap is negligible. The expected influence of the EBRD indicators on FDI inflows is positive (EBRD, 2014).

The Wall Street Journal and The Heritage Foundation publish the Index of Economic Freedom that covers 10 freedoms grouped into four broad categories: rule of law, limited government, regulatory efficiency and open markets. Each of these freedoms is scored on a scale of 1 to 100 , where 100 represent the maximum freedom.

Transparency International measures levels of corruption in the public sector, and assesses the Corruption Perception Index (CPI). It is a composite index, a combination of polls, drawing on corruption-related data collected by a variety of reputable institutions. A scale of $0-100$ is applied to measure the perception of corruption, where 0 means that a country is perceived as highly corrupt and 100 means that a country is perceived as not corrupt. The expected impact of the CPI on FDI inward stock is positive (a higher score means less corruption).

The model will include the following institutional variables: EBRD transition indicators (enterprise restructuring, trade and forex systems), property rights freedom from the Heritage Foundation, and the corruption perception index from Transparency International. The data set covers the period 2000-2012.

The relationship between FDI inward stock and their determinants is as follows:

FDI inwardstock ${ }_{\mathrm{it}}=\alpha+\beta_{1}$ GDP per capita ${ }_{\mathrm{it}}+\beta_{2}$ wages $_{\mathrm{it}}+\beta_{3}$ inflation $_{\mathrm{it}}+\beta_{4} \mathrm{X}_{\mathrm{it}}+\varepsilon_{\mathrm{it}} \quad \mathrm{i}=1 \ldots \mathrm{N} ; \mathrm{t}=1 \ldots \mathrm{T}$

Where the dependent variable is FDI inward stock and the independent variables are: GDP per capita, inflation, wages, and institutional variables: enterprise restructuring, corruption perception index, property rights freedom, trade and forex systems.

Considering that the sample has a cross-sectional dimension, represented by countries $(\mathrm{i}=1 ;::: ; \mathrm{N})$ and a longitudinal dimension, represented by a time series $(\mathrm{t}=1 ;:::$; T periods $)$, the panel data method will be used (Hsiao, 2003). We included in the analysis all observed countries except Kosovo due to lack of data. The sample comprises unbalanced panel data, i.e. there are some time periods missing from some units in the population of interest.

We used random effects (RE) and fixed effects (FE) estimation methods, which allow us to deal with the problem of unobserved heterogeneity. All models are tested using the Hausman test to decide between RE and FE and standard errors that are robust to heteroscedasticity and autocorrelation. The use of fixed effects is most certainly warranted.

The dependent variable and control variables (FDI inward stock, GDP per capita, inflation, wages, tax rates) were logged to interpret the coefficient as elasticities. Furthermore, taking logs enabled us to scale down the variation in data and generate better results in terms of statistical significance and standard errors. The institutional variables are constructed as indices and therefore are not logged. All models are corrected for autocorrelation and heteroscedasticity by using cluster robust standard errors. The results are presented in Table 7.

\subsection{Results}

The total number of respondents was 37; however, all respondents did not answer all questions (some questions are not obliged to be completed). Among these institutions, 18 of them are not involved in the operations with foreign investors or did not complete the survey correctly and therefore excluded. Finally, we were left with 19 respondents of which $29.7 \%$ deal at the national level and $70.3 \%$ at the regional level. Most of the respondents come from Croatia (59\%), 27\% come from Bosnia and Herzegovina, 11\% from Kosovo, and 1.5\% from Serbia and Macedonia. We did not receive any answer from Albania and Montenegro.

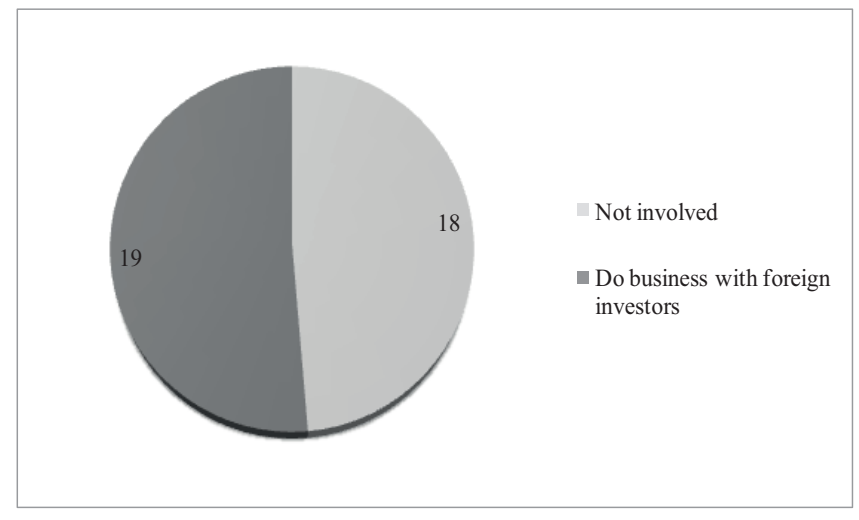

Fig. 1 Number of agencies/institutions that are/are not involve in the cooperation with foreign investors.

(Source: author's calculation based on survey's results.)

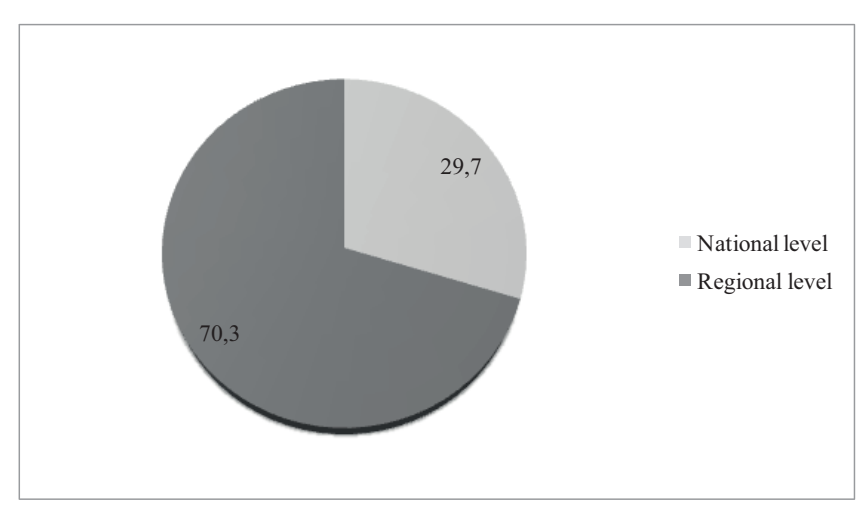

Fig. 2 IPA- national or regional level (in \%)

(Source: author's calculation based on survey's results.) 


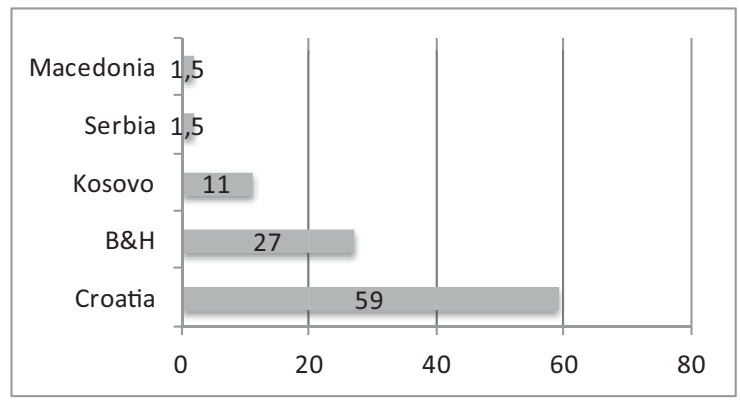

Fig. 3 IPA structure by countries (in \%)

(Source: author's calculation based on survey's results.)

Next, we are going to present and comment on the results of specific important questions. Most of the agencies are youngthey were established between 1999 and 2013 (most of them was established after 2005). Number of employees who work with foreign investors is very small (in 13 cases it is in the range $0-3$ ) and only in 6 cases there are more than 10 people available to foreign partners. The employees are predominantly highly educated $(70 \%)$ with the average monthly net salary higher than 500 euro (53\% of respondents).

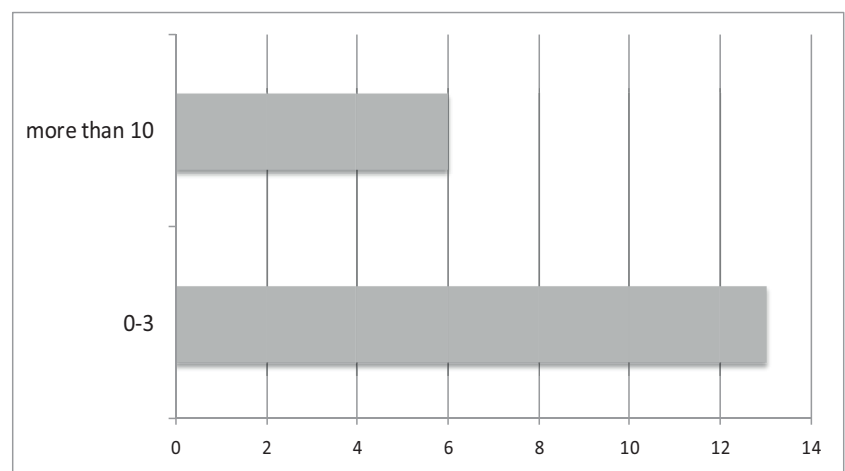

Fig. 4 Number of employees in charge to work with foreign investors (Source: author's calculation based on survey's results.)

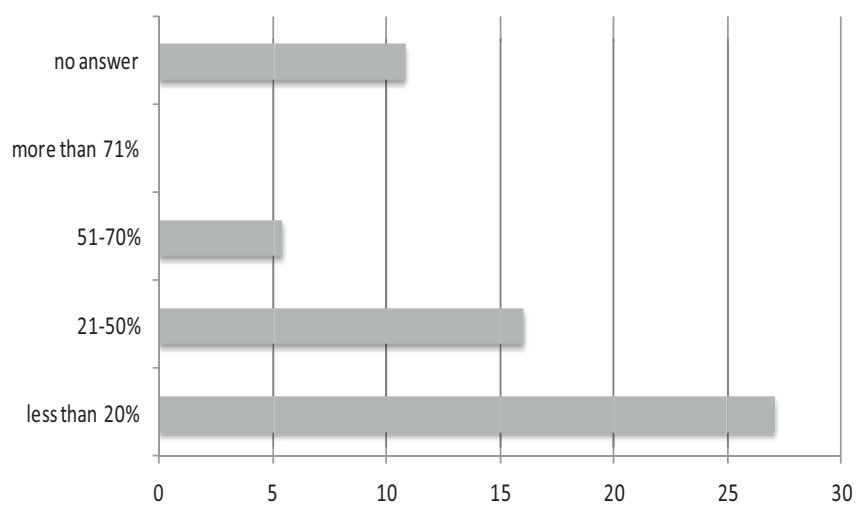

Fig. 5 Estimation of the intermediation role of IPA in FDI inflows in a particular region/country

On the question about the annual budget for FDI promotion, we obtained only nine answers of which only three IPAs gave concrete data. This is very disappointing because this limits their activities and possibilities to capture a more active position in the area of cooperation with foreign investors.
$27 \%$ of respondents estimate their intermediation in less than $20 \%$ of total FDI in a particular country/region; $16 \%$ of them estimate that they have participated in $21-50 \%$ of investment projects; $5.4 \%$ think their share is $51-70 \%$, and no agency has participated in more than $71 \%$ of investment projects in particular country/region (10.8\% of respondents did not give answer on this question). Most of the IPAs continue to cooperate with foreign investors in post-investment stage (81\%).

Tables 2-6 shows the attitudes of IPA's staff about: information/service provided to foreign investors (Table 2); the main obstacles for realization of investment in a particular country/region (Table 3); the main benefits of FDI in a particular country/region (Table 4); disadvantages from FDI in a particular country/region (Table 5) and the reasons for unfavourable effects of FDI (Table 6).

Table 2 Information/services provided to foreign investors by IPA (average rank)

\begin{tabular}{cc}
\hline Information about: & Rank \\
\hline tax system in your country & 3.13 \\
\hline infrastructure development & 3.09 \\
\hline procedure of establishment of firm & 3.5 \\
\hline reliefs for foreign investors & 4.27 \\
\hline specific locality in your country/region & 4 \\
\hline legal system & 4.91 \\
\hline educational structure in a particular region/city & 5.09 \\
\hline
\end{tabular}

Source: author's calculation based on survey's results.

The respondents should rank the answers where

the 1 represents the most important rank.

The numbers in figures are average ranks where the lowest rank shows the higher importance. The most often required information was about the infrastructure development, the tax system, and the procedure of establishment of the firm. These are the basic information for bring a decision of investment locality and for starting a business.

Table 3 The main obstacles for realization of investment in a particular country/region

\begin{tabular}{cc}
\hline & Rank \\
\hline institutional development & 3.75 \\
\hline tax policy & 4.1 \\
\hline macroeconomic stability & 3.25 \\
\hline infrastructure development & 3.55 \\
\hline corruption & 3 \\
\hline administration and justice & 3.35 \\
\hline
\end{tabular}

Source: author's calculation based on survey's results.

The respondents should rank the answers where the 1 represents the most important rank.

The IPA's staff recognized corruption, macroeconomic (in) stability, and administration and justice as the most important obstacles for FDI presence. 
Table 4 The main benefits of FDI in a particular country/region

\begin{tabular}{cc}
\hline & Rank \\
\hline inflows of capital & 2.8 \\
\hline transfer of technology & 2.67 \\
\hline access to new markets & 3.04 \\
\hline new employment opportunities & 4.09 \\
\hline improved competition at domestic market & 4.61 \\
\hline improvement of management performance & 3.76 \\
\hline \multicolumn{3}{c}{ Source: author's calculation based on survey's results. } \\
The respondents should rank the answers where \\
the 1 represents the most important rank.
\end{tabular}

Inflows of foreign capital are contributing to: transfer of technology, inflows of necessary capital (financial resources), and access to new markets. FDIs are not just a positive feature and the most important disadvantages from FDI inflows are: demands on government subsidies, crowding out local investors, reduced $R \& D$ activities, and negative impact on employment.

Table 5 Disadvantages from FDI inflows in a particular country/region

\begin{tabular}{cc}
\hline & Rank \\
\hline crowding out local investors/firms & 3.9 \\
\hline reduced research and development activities & 4.15 \\
\hline increased unemployment & 4.6 \\
\hline excessive dependence on foreign investor's decisions & 4.75 \\
\hline increased dependence on selected export markets & 5.25 \\
\hline increased dependence on foreign instead of local suppliers & 5.2 \\
\hline reduced competition on the domestic market & 4.55 \\
\hline demands on government subsidies & 3.74 \\
\hline $\begin{array}{c}\text { Source: author's calculation based on survey's results. } \\
\text { The respondents should rank the answers where } \\
\text { the 1 represents the most important rank. }\end{array}$ \\
\hline
\end{tabular}

These disadvantages resulted in the first place from unfavourable economic conditions and legal structure in a country.

Table 6 The reasons for unfavourable impact of FDI

\begin{tabular}{|c|c|}
\hline & Rank \\
\hline unfavorable general economic conditions & 2.94 \\
\hline $\begin{array}{c}\text { lack of consistent legal and policy environment attracts only } \\
\text { investors with speculative motivation }\end{array}$ & 3.16 \\
\hline $\begin{array}{l}\text { our regulatory framework and implementation policies did not } \\
\text { provide effective protection of the interests of our economy }\end{array}$ & 4.11 \\
\hline $\begin{array}{l}\text { due to our poor negotiation skills, unfavorable conditions } \\
\text { were accepted, and foreign owners do not care when hurting } \\
\text { our economic interests }\end{array}$ & 4.16 \\
\hline inadequate local competition policy & 4.94 \\
\hline lack of local suppliers & 4.42 \\
\hline $\begin{array}{l}\text { excessive technology gap prevent more absorption of foreign } \\
\text { knowledge }\end{array}$ & 4.26 \\
\hline
\end{tabular}

Source: author's calculation based on survey's results.

The respondents should rank the answers where the 1 represents the most important rank.
The qualitative aspects of FDI has also been analysed where the respondents had to answer about the reliefs for investments in the specific sectors, point the specific sectors, and answer about employees specialized for particular industries sectors. The main findings are:

- only 3 IPAs have defined budget for the activities with foreign investors,

- only 5 IPAs say that the country/region has some special reliefs for investments in some specific sectors,

- $24 \%$ of IPAs have targeted specific industry, that is, respondents state the specific sectors. According to their answers the five most important sectors are: wood industry, food production, agriculture; computer industry and automotive industry. ${ }^{4}$

We can classify the agencies in the SEE region as "Keynesian" according to Kunčić and Svetličić (2011) because the government subsidies (fiscal relief) are the main factor of attractiveness for FDI according to the IPAs staff opinion based on their experience and communication with foreign investors.

The results of panel data analysis are presented in Table 7.

The first model includes the economic location determinants of a particular market: GDP per capita, inflation, wages, corporate tax rates and corruption perception index. GDP per capita is used as a proxy for purchasing power in the host country, inflation as a proxy for price stability, and wages reflect the labour costs to which the efficiency type of FDI is very sensitive. Tax rates regard corporate tax rate and they are indicator of tax burden in the economy. GDP per capita, wages and tax rates have significant impact, where the impact of GDP p.c. has the expected sign, while wages and tax rates have positive sign and we would expect negative sign (more FDI if the wages and tax rates decrease). The reason can be that the highest level of FDI inward stock was recorded in Croatia which has the highest wages and also the highest level of corporate tax rate. Model 2 includes property rights freedom but this variable is not significant. The Model 3 incorporates enterprise restructuring and model 4 includes reforms in trade and exchange rate policies where both variables are significant. The variable inflation is significant only in Model 3 whit expected negative influence on FDI inward stock.

The results are in line with the IPA's staff opinion where they indicate high rank to providing information about tax system to foreign investors. Corruption, as recognized problem by IPA's staff, in the Model 1 doesn't have significant impact on FDI inward stock, but macroeconomic stability (inflation, enterprise restructuring; trade and forex system) is important for FDI attractiveness.

4 The ranking of industries are not the same among the respondents. 
Table 7 Determinants of FDI inward stock in Southeast European countries in period 2000-2012

\begin{tabular}{|c|c|c|c|c|}
\hline & Model 1- FE & Model 2-FE & Model 3-FE & Model 4 -FE \\
\hline GDP p.c. & $\begin{array}{c}1.517411 \\
(0.2597628)^{* *}\end{array}$ & $\begin{array}{c}1.083594 \\
(0.4757307)\end{array}$ & $\begin{array}{c}1.905774 \\
(1.898528)\end{array}$ & $\begin{array}{c}2.330225 \\
(1.355271)\end{array}$ \\
\hline Wages & $\begin{array}{c}1.78299 \\
(0.3419058)^{* *}\end{array}$ & $\begin{array}{c}2.604246 \\
(0.5578249)^{* *}\end{array}$ & $\begin{array}{l}1.133224 \\
(1.56135)\end{array}$ & $\begin{array}{c}1.149762 \\
(1.332)\end{array}$ \\
\hline Inflation & $\begin{array}{l}-0.0464015 \\
(0.0413555)\end{array}$ & $\begin{array}{l}-0.0835105 \\
(0.0570484)\end{array}$ & $\begin{array}{c}-0.207206 \\
(0.0818923)^{* *}\end{array}$ & $\begin{array}{c}-0.203651 \\
(0.0873645)\end{array}$ \\
\hline Enterprise restructuring & & & $\begin{array}{c}1.452282 \\
(0.1697125)^{* * *}\end{array}$ & \\
\hline Trade and forex system & & & & $\begin{array}{c}0.8578597 \\
(0.3182811)^{* *}\end{array}$ \\
\hline Corruption & $\begin{array}{c}0.0537003 \\
(0.1096323)\end{array}$ & & & \\
\hline Property rights freedom & & $\begin{array}{l}-0.0146527 \\
(0.0175292)\end{array}$ & & \\
\hline Tax rates & $\begin{array}{c}1.309064 \\
(0.2329611)^{* *}\end{array}$ & $\begin{array}{c}1.543554 \\
(0.1479214)^{* * *}\end{array}$ & $\begin{array}{c}1.57272 \\
(0.3700599)^{*}\end{array}$ & $\begin{array}{c}1.38065 \\
(0.2207708)^{* * * *}\end{array}$ \\
\hline R-sq. & 0.90 & 0.95 & 0.86 & 0.89 \\
\hline Time fixed effects & Yes & Yes & Yes & Yes \\
\hline F test (p-value) & 0.0000 & 0.0000 & 0.0000 & 0.0000 \\
\hline Observation & 57 & 56 & 71 & 71 \\
\hline
\end{tabular}

All models include constant variable. Standard errors are in parenthesis. ${ }^{*} * \mathrm{P}$ statistically significant at $1 \%$. $*$ P statistically significant at $5 \% .{ }^{*} \mathrm{P}$ statistically significant at $10 \%$. Source: author's calculation.

\section{Conclusion}

The idea of this research is to determine the importance of FDI promotion agencies in attracting FDI in the South and East Europe countries. The research is done by analysing primary data obtained from the survey responses and by regression analysis. The hypothesis was that agencies (at national or regional level) have close contact with foreign investors and they can recognize the kind of information the investors required from them, the benefits and disadvantages from FDI inflows, the factor of attractiveness (reasons for FDI inflow) and also obstacles and unfavourable effect of FDI inflow in a particular country/ region. The fact is that as a large number of regional agencies in the SEE countries really do not work with foreign investors, investors need to contact national agencies. The situation is different in Croatia and Kosovo where regional agencies also participate in investment process. IPAs in the SEE region are young-they were established between 1999 and 2013 (most of them was established after 2005).

In the quantitative part of the research we have performed panel data analysis to find out the main determinants of FDI inward stock in the SEE countries including economic and institutional variables. The models show that GDP per capita, wages, inflation and tax rates have influence on FDI inward stock, but also enterprise restructuring and trade and forex system, as institutional variables.

The general findings show that the national and regional agencies role in attracting FDI is underutilized, especially with regard to regional agencies where in most countries they have played a very limited role or they do not have a role to cooperate with foreign investors. They are involved in a very small share of total FDI inflows in their countries, and usually they have no defined specific budget for FDI-promoting activities. Probably the foreign investors have found their own ways for penetrating the markets in SEE countries-maybe through the consultation firms or their chamber of commerce's/branches they have in the SEE countries.

The IPAs at national and regional level should have a more important role in cooperation with foreign investors; a more proactive approach in required with a lot of particular information on possibilities of investments and also with emphasized sectors of specific interests. It should be in line with the national policies for attracting FDI (laws, strategic goals, increasing competitiveness).

The results obtained from this research provide an important review of IPAs and their effectiveness in attracting FDI in the SEE region. This review can be useful for policymakers at different levels to define and focus the IPAs toward foreign investors 
as more FDI inflows in all SEE countries are very desirable and promising for relaunching/increasing production, employment, and export. They cannot solve the mentioned problematic areas for investments but with the more coherent and transparent policy (at all levels) toward potential investors they can help bridge the many difficulties that foreign investors are facing.

\section{References}

Basinger, S. J., Hallerberg, M. (2004) Remodeling the Competition for Capital: How Domestic Politics Erases the Race to the Bottom. American Political Science Review. 98 (2). pp. 261-276. DOI: $10.1017 / \mathrm{s} 0003055404001133$

Bénassy-Quéré, A., Coupet, M., Mayer, T. (2007) Institutional Determinants of Foreign Direct Investment. The World Economy. 30 (5). pp. 764-782. DOI: 10.1111/j.1467-9701.2007.01022.x.

Blonigen, B.A. (2005) A review of the empirical literature on FDI determinants. NBER Working Paper, No. 11299. Available from: http://www. nber.org/papers/w11299 (Accessed: 4th March, 2013)

Brainard, S.L. (1997) An empirical assessment of the proximity concentration tradeoff between multinational sales and trade. American Economic Review. 87 (4). pp. 520-544.

Cass, F. (2006) Attracting FDI to transition countries: the use of incentives and promotion agencies. UNCTAD. Available from: http:/unctad.org/ en/docs/iteiit20072a3_en.pdf (Accessed: 8th January 2014).

Charlton, A., Davis, N. (2007) Does Investment Promotion Work?. The B.E. Journal of Economic Analysis \& Policy. 7 (1). pp. 1935-1682. DOI: $10.2202 / 1935-1682.1743$

Damijan, J., Kostevc, Č., Rojec, M. (2013) FDI, Structural Change and Productivity Growth: Global Supply Chains at Work in Central and Eastern European Countries. IRMO Occassional Paper, No.1. Available from: http://www.irmo.hr/files/IRMO\%20OP\%201_2013\%20sa\%20 ISSN.pdf (Accessed: 23th January, 2014).

Deichmann, J. I. (2010) Foreign Direct Investment in the Czech Republic: The Role of Origin Effects and Government Promotion Abroad'. Comparative Economic Studies. 52 (2). pp. 249-272. DOI: $10.1057 /$ ces.2010.1

Dunning, J. (1992) Trade, location and economic activity and the multinational enterprise: a search for an eclectic approach. In: Dunning, J. (ed.) The Theory of Transnational Corporation. Vol. 1. pp. 183-218. New York: Routledge.

Dunning, J. (1993) Multinational enterprises and the global economy. Workingham: Addison Wesley.

EBRD (2014) Transition Report. Available from: http://www.ebrd.com/pages/ research/publications/flagships/transitions.html

Egger, P., Winner, H. (2005) Evidence on corruption as an incentives for foreign direct investments. European Journal of Political Economy. 21 (4). pp. 932-952. DOI: 10.1016/j.ejpoleco.2005.01.002

Guimon, J., Filippov, S. (2012) Competing for High-quality FDI: Management Challenges for Investment Promotion Agencies. Institutions and Economies. 4 (2). pp. 25-44.

Guimon, J. (2009) Government strategies to attract R\&D-intensive FDI?." Journal of Technology Transfer. 34. pp. 364-379. DOI: 10.1007/s10961-008-9091-1

Hsiao, C. (2003) Analysis of panel data. Cambridge: Cambridge University Press. Hughes, M., Helinska-Hughes, E. (2002) Joining the Competition: Central and East European Challenge to Established FDI Destinations. In: Phelps, N., Raines, P. (eds.) The New Competition for Inward Investment, Institutions and Territorial Development. pp. 155-172. Cheltenham: Edward Elgar Publishing Limited.
Hunya, G. (2000) Recent FDI Trends, Policies and Challenges in South-East European Countries'. wiiw Research Reports, No. 273, The Vienna Institute for International Economic Studies.

Kaufmann, D., Kraay, A., Mastruzzi, M. (2004) Governance Matters: Governance Indicators for 1996-2002. World Bank Policy Research Working Paper, 3106. Available from: http://papers.ssrn.com/sol3/ papers.cfm?abstract_id=405841 (Accessed: 22nd February 2014).

Kemeny, T. (2010) Does Foreign Direct Investment Drive Technological Upgrading?. World Development. 38 (11). pp. 1543-1554.

Kinoshita Y., Campos, N.F. (2002) The location determinants of foreign direct investment in transition economies. Available from: http://project.iss.utokyo.ac.jp/nakagawa/members/papers/3\%289\%29kinoshita.final.pdf (Accessed: 7th January 2014)

Kunčić, A., Svetličič, M. (2011) Who's Who in Foreign Direct Investment Promotion, Keynesians Versus Neoclassicals. Eastern European Economics. 49 (3). pp. 66-88. DOI: 10.2753/eee0012-8775490304

La Porta, R., Lopez-de-Silanes, F., Shleifer, A., Vishny, R. (1999) The Quality of Government. Journal of Law, Economics and Organization. 15 (1). pp. 222-279. DOI: 10.1093/jleo/15.1.222

Lim, S.-H. (2008) How investment promotion affects attracting foreign direct investment: Analytical argument and empirical analyses. International Business Review. 17 (1). pp. 39-53. DOI: 10.1016/j.ibusrev.2007.09.001

Markusen, J. R. (1998) Multinational firms, location and trade. World Economy. 21 (6). pp. 733-756.

Markusen, J. R., Venables, A.J. (1998) Multinational firms and the new trade theory. Journal of International Economics. 46. pp. 183-203. DOI: 10.1016/s0022-1996(97)00052-4

Mencinger, J. (2003) Does Foreign Direct Investment Always Enhance Economic Growth?. KYKLOS. 56 (4). pp. 491-508. DOI: $10.1046 / \mathrm{j} .0023-5962.2003 .00235 . x$

Morisset, J. (2003) Does a Country Need a Promotion Agency to Attract Foreign Direct Investment? A Small Analytical Model Applied to 58 Countries. World Bank Policy Research Working Paper Series. No. 3028.

Morisset, J., Andrews-Johnson, K. (2004) The effectiveness of Promotion Agencies at Attracting Foreign Direct Investment. Washington, D.C.: IBRD/World Bank.

OECD (2003) Investment Promotion and Facilitation. Available from: http:// www.oecd.org/daf/inv/investment-policy/40287315.pdf (Accessed: 7th January, 2014).

Raines, P. (1998) Regions in Competition: Inward Investment, Institutional Autonomy and Regional Variation in the Use of Financial Incentives. Regional and Industrial Policy Research Paper Series. No. 29, EPRC, University of Strathclyde. Available from: http://www.eprc.strath.ac.uk/ eprc/documents/pdf_files/r29regionsincomp.pdf (Accessed: 2nd January, 2014).

Raines, P., Wishlade, F. (1999) EC Policymaking and the Challenge of Foreign Investment. In: Phelps, N., Alden, J. (eds.) FDI and the Global Economy: Corporate and Institutional Dynamics of Global-Localisation. London: Jessica Kingsley.

Šimelyte, A. (2012) The Role of Investment Promotion in Attracting FDI: Evidence from the Baltic States. Economics and Business. 22. pp. 174180.

The Heritage Foundation (2014) The Index of Economic Freedom. Available from: http://www.heritage.org/index (Accessed: 7th December 2014)

Transparency International (2014) Corruption Perception Index. Available from: http://www.transparency.org/research/cpi/overview (Accessed: 7th December 2014)

UNCTAD (1998) World Investment Report 1998: Trends and determinants. Available from: http://unctad.org (Accessed: 7th December, 2014). 
UNCTAD (2001) The World Of Investment Promotion At A Glance A Survey of Investment Promotion Practices. New York and Geneva: United Nations.

UNCTAD (2008) Evaluating Investment Promotion Agencies. Investment Advisory Series, Series A No. 3. Available from: http://unctad.org/en/ docs/diaepcb20082_en.pdf(Accessed: 15th January, 2014).

WAIPA (2012) Annual report 2011-12. Available from: http://www2.waipa. org/export/sites/default/Waipa/Gallery/waipa_web_final.pdf (Accessed: 7th December 2013)

Wells, L. T. (1999) Revisiting Marketing a Country: Promotion as a Tool for Attracting Foreign Investment. CUTS Centre for International Trade, Economics \& Environment. Available from: http://www.cuts-citee.org/ CDS03/pdf/CDS03-Session5-02.pdf (Accessed: 7th December 2013)
Wells, L. T., Wint, A. G. (1990) Marketing a country: promotion as a tool for attracting foreign investment. FIAS Occasional Paper, No.1.

Wells, L. T., Wint, A. G. (2000) Marketing a Country: Promotion as a Tool for Attracting Foreign Investment. Washington, D.C.: IFC MIGA and World Bank (Revised Edition).

WIIW (2013) Handbook of Statistics. Central, East and Southeast Europe.

\section{Appendix.}

Table Correlation matrix

\begin{tabular}{|c|c|c|c|c|c|c|c|}
\hline & logwages & logtax s & $\log f d i \sim 0$ & $\operatorname{loginf\sim n}$ & $\log G D P p c$ & enterp g & tradea m \\
\hline logwages & 1.0000 & & & & & & \\
\hline logtaxrates & 0.0711 & 1.0000 & & & & & \\
\hline logfdiinwa o & 0.6791 & 0.2874 & 1.0000 & & & & \\
\hline loginflation & -0.2764 & -0.2864 & -0.2347 & 1.0000 & & & \\
\hline $\operatorname{logGDPpc}$ & 0.8462 & 0.1099 & 0.6789 & -0.0764 & 1.0000 & & \\
\hline enterprise g & 0.6379 & 0.5411 & 0.7493 & -0.4282 & 0.6814 & 1.0000 & \\
\hline tradeandfo m & 0.2332 & 0.5179 & 0.4981 & -0.5429 & 0.3125 & 0.7219 & 1.0000 \\
\hline corpercept $\sim$ x & 0.7613 & 0.0925 & 0.6651 & -0.0860 & 0.7881 & 0.6065 & 0.2475 \\
\hline \multirow[t]{2}{*}{ propertyri m } & 0.1152 & 0.2238 & 0.3436 & 0.1514 & 0.5240 & 0.5010 & 0.4714 \\
\hline & corper $x$ & proper m & & & & & \\
\hline corpercept x & 1.0000 & & & & & & \\
\hline propertyri m & 0.3479 & 1.0000 & & & & & \\
\hline
\end{tabular}

Table Descriptive statistics

\begin{tabular}{|c|c|c|c|c|c|}
\hline Variable & Obs & Mean & Std. Dev. & Min & $\operatorname{Max}$ \\
\hline enterprise g & 78 & 2.240897 & .4809276 & 1 & 3.3 \\
\hline tradeandfo m & 78 & 3.841282 & .6670021 & 1 & 4.33 \\
\hline competitio y & 78 & 1.92641 & .6741362 & 1 & 4 \\
\hline corpercept x & 62 & 3. 316129 & .5879092 & 2.3 & 4.8 \\
\hline propertyri m & 62 & 28.30645 & 9.621678 & 10 & 40 \\
\hline $\operatorname{logGDPpc}$ & 78 & 8.857739 & .3777053 & 8.064636 & 9.674074 \\
\hline loginflation & 74 & 1.389167 & .9532917 & -.6979632 & 4.535811 \\
\hline logfdiinwa o & 74 & 7.890845 & 1.523312 & 1.548498 & 10.3216 \\
\hline logtaxrates & 78 & 2.510367 & .3233422 & 2.197225 & 2.995732 \\
\hline logwages & 78 & 5.971967 & .5825887 & 4.612443 & 6.960262 \\
\hline
\end{tabular}

